\title{
Taboos and Euphemisms in Social Interaction: A Socio-Pragmatic Analysis of Papiackum Proverbs
}

\author{
Moustapha Reike Fandi \\ Department of African Languages and Linguistics \\ The University of Yaoundé I \\ Cameroon \\ E-mail: reikemoustapha@yahoo.co.uk
}

\begin{abstract}
This study emanates from the observation that most people in recent times stand the risk of non-exposure to the wits in oral tradition in the face of rapid advancement in science and technology. In this light, orature which used to be a source of knowledge and entertainment is losing grounds in favour of the latest gadgets of New Information and Communication Technology because they provide alternative sources of knowledge and entertainment. Proverbs, an element of orature, are considered in most African communities to be embedded with wits and the art of discourse. Based on these considerations and from the prism of Speech Act theoretical paradigm, this study examines the wits that are projected when euphemisms are expressed through proverbs. In this guise, this study is based on the premise that, in the expression of taboos via euphemisms, moral principles and philosophy of life are also brought to the fore. Papiackum, which is the speech community under study, is in the Ngoketunjia Division, North West region of the Republic of Cameroon.
\end{abstract}

Keywords: Taboos, Euphemisms, social interaction, proverbs.

\section{Introduction}

In sociological discourse, it is affirmed that the human being is a social animal. This means that he is a member of a society where he interacts with one another. This makes the behavior of man to be largely determined by their relation with each other and by their membership in groups. For a better correspondence with his kind, man has invented the skills of language which is an invaluable tool for socialization and the transmission of culture whose main elements are its norms, values, symbols and language. In this light, Bassis, Gelles and Levine (1988) point out that, the capacity for symbolic communication through language, sets humans apart from other animals. This means that human language is enriched with utterances that project certain norms and values.

This view is corroborated by Brown and Selznick (1968) who affirm that socialization is a reality in every community because man has the inborn capacity to use language. In this guise, it is a mastery of a language in its socio-cultural context that makes man a good interactant in his community. In other words, for a peaceful and harmonious cohabitation of humans, there must be the conscious effort to link language used to the norms and values dictated by the context in question. It is in respect of the aforementioned principle, that in the course of social interaction, humans avoid face threatening acts or acts that put to question their morality. As a result, since socialization is imminent in any society, humans are always indulged in one way or the other in the promotion of social interaction. In the Papiackum community, proverbs are used as an essential conversational tool in social interaction to interrogate behaviour as well as pass across messages which could be political, economic, socio-cultural or otherwise for the smooth functioning of society.

This study aims at projecting the taboos embedded in euphemistic usages in some Papiackum proverbs while highlighting their moral and philosophical undertones. It is, therefore, grounded on the premise that proverbial expressions project euphemistic usages that delineate taboos, moral principles and philosophy of life of the speech community under study.

\section{Definition of Concepts}

To provide a clearer view of the key concepts of this study, this section provides an elaborate definition of taboos, euphemisms, social interaction and proverbs. The word 'taboo' has its etymological roots in Polynesian society which means sacred or holy. It is worth noting that the use of taboos in English dates back to 1777 when Captain James Cook, an English explorer visited Tonga. On his first voyage of 1768-1771, he was sent to Tahiti to observe the transit of the planet Venus across the sun. 
While on this voyage, he observed the Tahitians closely and noticed some prohibitions amongst them. In his logbook, he affirmed that Tahitian women do not eat with men and when it is done, it is not publicly. After this observation, Cook did not link this practice to the word 'taboo'.

It was in the log of his third voyage of $1776-1779$ that he used the said term. In relation to the Tahitian society therefore, Cook (1967) in his entry of 17 July 1777, wrote about taboo thus:[...] Taboo as I have observed is a word of extensive signification; Human sacrifices are called Tangata. Taboo, and when anything is forbid to be eaten, or made use of they say such a thing is Taboo; they say that if the King should happen to go into a house belonging to a subject, that has would be Taboo and never more be inhabited by the owner; so that whenever he travels there are houses for his reception (p.176).

The citations above clearly indicates that Cook's use of the term 'taboo' was in relation to all that was outlawed among the Tahitians given that it highlights practices that are culturally forbidden. In the same light, Allan and Burridge (2006) relate taboos to behavior as they refer to it as a proscription of behavior for a specifiable community of one or more persons at specifiable time in specifiable contexts. To support this view, they allude to the pacific islands which was first visited by Europeans who believe that taboos prohibited certain people either permanently or temporarily from certain actions, from contact with certain things and certain people thus a taboo person was ostracized. They further affirm that the said term came to be used with reference to similar customs elsewhere in the world especially when such prohibitions arise from respect for, fear of and metaphysical powers. To expatiate on this, they opine that taboos cut across political, social affairs and extend to the interdiction of the use or practice of anything especially an expression or topic considered offensive and therefore avoided by social custom. In this connection, in the speech community under study, taboo topics or subjects are reflected in their utterances through euphemistic expressions. The word 'euphemism' has its etymological roots in the Greek word 'eu' meaning good and 'pheme' meaning speech or saying. It thus literarily means to speak with good words. Abrams (1999) defines euphemism as an inoffensive expression used in place of a blunt one that is felt to be disagreeable or embarrassing. Allan and Buridge (2006) believe that for the term 'euphemism' to be well understood, it has to be defined alongside its sisterly terms such as dysphemism and orthophemism. To them, euphemisms are words or phrases used as an alternative to a dispreferred expression as they avoid possible loss of face by the speaker, hearer or some third party. As for dysphemism, they posit that there are words or expressions with connotations that are offensive either about the denotatum or to people addressed or overhearing the utterance. In relation to orthophemism, they state that it is a typically more formal and more direct way of referring to things. All in all, euphemistic usages which are partly the focus of this study are used by the community under study as a means of censoring their language used in specific contexts in order to meet their face wants. In social science, a social interaction or social relations depicts a relationship between two, three or more individuals. In this light, Turner (1988) defines social interaction as a situation where the behaviors of one actor are consciously reorganized by and influence the behaviors of another actor and vice versa. In the same light, Bloom and Selznick (1968) view social interaction as the process of acting in awareness of others and adapting responses to the way others respond. To further asseverate this view, Blumer (1986) examines the nature of society when he underscores thus: Group life necessarily presupposes interaction between the group members, put otherwise; a society consists of individuals interacting with one another. The activities of the members occur predominantly in response to one another or in relation to one another (p. 7)

The citations above reiterate the primordial role of interaction in every human society. This is facilitated by the human capacity to indulge in social actions based on his feelings, the feelings of others and rules governing conversation in a particular context. In other words, interaction is an ongoing process in every community which is successful in a given context though mutual understanding and collaboration amongst its members. In this light, interactants will have to interpret each other's action both at the symbolic and non-symbolic level in order to adjust their actions.

Oral narratives have been a subject of interest to literary scholars who prefer to term it oral literature among whom is Talla (2013) who segments it into folktales, myths, legend, and wisdom literature. Thus, he classifies proverbs and riddles as wisdom literature while affirming that proverbs are a fundamental ingredient in the intellectual tradition of Cameroonians. As regards the essential features of proverbs, he mentions their didacticism of content and conciseness of from. He further notes that proverbs originate from everyday activities and are used by elders as a guide to conduct, an aid to moral lessons, a prop of oratory, represent some homely truths and are framed around a central image which reflects aspects of rural life. Vansina (1985) on his part, views oral traditions as verbal messages which are reported statements from the past beyond the present generation and there must be transmission by word of mouth over at least a generation. He further outlines the dynamic processes of oral tradition which ranges from memorized speech, accounts, epic, and proverbs to sayings. In relation to memorized speech, he posits that once it is created, the contents to be memorized are supposed to remain unchanged from recitation to recitation although its actual wording will vary over time. 
As for accounts, he segments them into historical gossip, personal tradition, group account, traditions of origin and genesis and cumulative accounts $\mathrm{He}$ affirms that historical gossip in the result of news and hearsay generated as events occur and communicated through the usual channels of communication.

He refers to personal tradition as family traditions known and told by one or more people even after the death of the person whose reminiscences they were. Furthermore, he views group account as the oral memories of groups such as villages, chiefdoms, kingdoms, associations and various kinship groups. As regards traditions of origin and genesis, he affirms that every community in the world has a representation of the origin of the world, the creation of mankind and the appearance of its own society and community. In relation to cumulative accounts, he states that they are accounts such as lists or genealogies which have to be continually updated as they form a basis for the local chronology by providing epochs and units of duration used to evaluate how far in the past something happened. As for an epic, he notes that it is a class of traditions on its own which mostly has a historical dimension and the hero once really lived or some of the incidents usually the main plot correspond to actual events of minor or major importance. With respect to tales, he posits that they are performed in everyday language chosen by the performer and a certain amount of innovation is highly appreciated even though they are considered as fiction. With respect to proverbs and sayings, he notes that they also belong in this class of traditions where neither exact wording nor any special linguistic form is required of them. He further asserts that large scale collections of proverbs and saying bear the variability in wording while stressing that the dynamics of proverbs and sayings are not well known given that they seem to endure like any metaphor in a language. As a technique of communication, the Papiackum community has and is still using proverbial expression in their daily interactions. In this guise, their proverbs are locally referred to as sab Papiackum meaning the proverbial expression of Baba I people. These proverbs are either expressed as a declaratory statement or as a rhetorical question in their daily interactions. They are always termed the 'people' tales because they belong to the entire community. In the said community, proverbial discourse is recurrent in the utterances of elderly people who most often are considered as the custodians of wisdom. They derive meaning in context when interpreted at the non-literal or at the symbolic level.

\section{Literature Review}

There exist a number of scientific articles on proverbial discourse as scholars have analyzed them from different perspectives and cultural settings. Inasmuch as these wide range of opinions serve as a background to this study, they equally shed light as well as isolate it. To begin with, Babasola (2014) studies the nature, from and functions of Yoruba proverbs from the prism of socio-pragmatics. The findings reveal that, in relation to nature, Yoruba proverbs are connected with stories while others are clearly related to anecdote. In terms of style, he notes that, there is the literal form comprise of allusions, metaphors, hyperbole and picturesque form of speech. In relation to functions, their roles range from educational, rhetorical to anecdotal. Lee (2005) examines the representation of woman and men in Chinese proverbs. This study reveals that not all proverbs offer good advice as there are some that carry within them gender discrimination and stereotypes. In this light, he notes that, although women are not underrepresented in Chinese proverbs, over half of the proverbs describing women are about their physical attributes implying that a woman's importance lies in her physical beauty while men are treated with a focus on features such as talents, bravery, friendships and sexual desire. Arinola (2009) dwells on figures of association and sound in some Ondo proverbs. It reveals that figures of association mostly used are simile, metaphor and personification. As regards figures of sound, it comprises alliteration, consonance and onomatopoeic idiophone. By extension, this study has established that figurative language performs the same aesthetic function in proverbs as it does in poems.

Ademowo and Balogun (2014) examine the invaluable nexus between language and development with particular emphasis on how the use of some Yoruba Proverbs and their lessons could help revive moral /cultural values and thus be used as a veritable instrument of development. This study reveals that Yoruba proverbs do not only make the people conform to desired rules, mores and tradition of the land but also teach a method of expressing life which is aesthetically flavored. In this light, he concludes that if concerted efforts are made to entrench effective pragmatic teaching and learning of these proverbs in homes and schools across levels, they would be veritable ingredients and instruments in quenching the thirst for quality people centered development. Amende (2013) examines proverbs as circumstantial speech act from the perspective that for the effective understanding of language use in traditional societies, proverbs should be incorporated into the study of discourse analysis, pragmatics and semantics of African folk languages. His study reveals that proverbs cannot be classified as solely a genre of oral literature because they are obligatory sentential items common in African Languages.

In this light, he affirms that because most languages are not written down, the folk pattern are their expressions along physical objects that can be seen, felt and touched in order to be remembered. He concludes by asserting that scholars 
of African languages may understand their subject better through the study of proverbs not as a literary genre but as items of folk languages.

\section{Theoretical Framework}

Speech Act theory was developed by John Langshaw Austin and later elaborated on by John Searle.

This theory came to replace logical positivism which was a major theoretical approach to the study of language that dominated part of last century. It is grounded on the prism that all utterances are to be evaluated exclusively on their verifiability. In this guise, if the truth of an utterance cannot be determined, the utterance is considered to be meaningless. Austin (1962) Speech Act theory stems from his observation that it is not possible to subject every utterance to a truth conditional analysis. This means that the truth embedded in utterances cannot be determined in all cases. As a consequence to his observation, he proposed a distinction between performative and constative utterances. In this light, he affirms that constatives are utterances for which a truth value could be determined while performatives are used to perform an action which changes the world in some way and cannot be subjected to a truth conditional analysis. On the basis of the problems he encountered through the performative-constative distinction, he abandoned it in favor of illocutionary forces or speech acts based on the contention that language is action-oriented. In other words, this marked the introduction of the concept of language performity.

To elucidate on the concept of language performity, he affirms that any utterance involves the simultaneous performance of three actions namely, locutionary, illocutionary and perlocutionary acts. The locutionary act is performed through a phonetic act comprising identifiable words; the phatic act is performed when these identifiable words are arranged on the basis of a particular grammar while the rhectic act gives them a certain sense and reference based on the context. As for the illocutionary act, it is the conventional force associated with the uttering of the words in a particular context. In other words, what is primordial at this level is the intended meaning and not the propositional meaning. In relation to the perlocutionary act, the speaker intends to produce certain effects upon the feelings, thoughts or actions of the audience.

Searle (1979) further extends the discourse on illocutionary point when he notes that there are five basic primitive illocutionary points namely, directives, commissives, declaratives, expressives and assertives. Directives are an attempt to commit a speaker to future course of action which include warning, promising, threatening and guaranteeing. Declaratives are an attempt to bring about a change in some institutional state of affairs like declaring war and performing a marriage. Expressive express a psychological state like thanking, complaining, greeting and apologizing. Commissives count as an attempt to commit the speaker to a future course of action while assertive count as an attempt to represent an actual state of affairs, to commit the speaker to something being the case such as asserting, concluding, informing and reporting. In addition, he also proposed an inferential approach to understanding indirect speech acts. In this guise, he affirms that indirect speech acts involve the performance of two distinct speech acts with a different illocutionary point namely, the literal illocutionary point and the intended illocutionary point that is conveyed via the performance of the literal illocutionary point. This leads to two fundamental questions namely; how does the hearer recognize that there is an ulterior speech act being performed? How does the speaker recognize what that ulterior act is? As an answer to these questions, he states that for a hearer to discover the primary illocutionary point, it involves two stages namely, recognition that the literal illocutionary force is not the intended act and that there is some other illocutionary act that is the intended act. This is based on the concept of conversational implicature proposed by Paul Grice in 1975.

As regards the concept of conversational implicature, it is grounded on the premise that for utterances to convey non literal meaning, interlocutors must abide by the cooperative principle which posits that people should communicate in a rational and efficient manner, say what they mean, just the facts, and do not wander around and so on. This idea put forth in this theory is summarized into four conversational maxims namely, quantity which requires utterances to be as informative as required, quantity which requires contributions to be one for which there is evidence. Manner means to avoid ambiguity and obscurity and relation which require a relevant contribution for the exchange.

\section{Geopolitical Presentation, Social History and Occupation}

Baba I whose language is the object of this study, is among the thirteen villages that constitute present day Ngoketunjia Division in the North West Region of the Republic of Cameroon. This village is situated at about forty kilometers from Bamenda along the ring road that leaves Bamenda to Nso. In the North, it shares a boundary with Oku which is a Sub Division in Bui Division. In the East, there is Babessi village. In the South East, it shares a short boundary with Bangolan which is among the four Fondoms that constitute Babessi Sub Division.

In the South, there are Bambalang and Bamunka Fondoms which are within Ndop central Sub Division. In the West, there is Babungo Fondom which constitutes one of the four Fondoms of Babessi Sub Division. As regards their origin, 
these people came from Refum which was the capital of the defunct Tikari Kingdom now known as Mbamkin in the Adamawa Region of Cameroon. They came from some places in North Cameroon like Maroua, Garoua and Ngaoundere. They left North Cameroon during the Jihad wars and moved to the South. It is alleged that they belong to the Tikari ethnic group and arrived North Cameroon from Egypt. When they arrived the South of Cameroon, they created their Fondom with the urge to foster their unity. They call their Fondom 'piack' which means 'to leave.

This coinage is the result of their history marked by migration before settling to their present site. Structurally, they have institutions that perform political and socio-cultural duties. Politically, mwarngang is the highest institution in this Fondom that has the power to sanction cases of indiscipline, enthrone a new chief and judge issues related to murder. Besides, there is the shag known as women's' parliament whose role is visible in times of conflict or war, is an association of Baba I Moslem women. It is a solidarity group that assists its members in difficult situations. In addition, some large families have esoteric societies which carryout death celebrations of their members.

As a manifestation of the African Communal lifestyle, all the Papiackums except the minors are divided into age groups. When each group of young people who are almost of the same age reaches the age of maturity, they form their age group and contact the chief (traditional ruler) to give them a name. In case all the members of an age group die, their property is taken to the palace after the death celebration of the last person. In terms of occupation, they practice agriculture with rice farming as their principal activity. They developed a lot of interest in rice cultivation when the prices of coffee fell in the world market. The cultivation of maize, beans, cassava and other food crops is also in vogue and done mostly by women. These crops both serve as food and cash crop for the well-being of the said population.

\section{Papiackum Proverbs as Discourse}

The term "discourse" is often used to denote an extended stretch of connected speech or writing. Foucault (1977) adds that, discourse is socially constructed knowledge of some aspects of reality. To foreground this view, Leeuwen (2005) affirms that socially constructed knowledge is one which has been developed in specific social contexts in ways that are appropriate to the interests of social actors in these contexts. Papiackum proverbs are a form of discourse which can only be interpreted in its entirety based on the contexts in which they are used. It is due to the preponderance of proverbs in Igbo discourse that Achebe (1958) comments that in the Igbo society, the art of conversation is regarded very highly and proverbs are the palm oil with which words are eaten. This proverbial expression is not only circumscribed within the Igbo society but could be seen as a symbolic representation of Africa where proverbs in conversation are highly encouraged and valued. It is within this view that Papiackum proverbs are studied. The method adopted to collect data for this study is the observation method where the information is sought by way of the investigator's own direct observation without asking from the respondent. The empirical world of this method is the natural world of such group life and conduct.

In the light of the above mentioned method, two contexts which serve as the empirical social world for euphemistic usages have been identified for the purpose of this study which is a burial and a fund raising ceremony. To begin with, the first interaction was during the burial ceremony of a Papiackum youth called Nchiminyi who died few months after his father called Moh Nkong. The news of the sudden death of the said youth was received with a lot of shock and pain. This could be partly because the cause of his demise was not made public giving room to speculations. In this guise, speculations in relation to death and death related issues are expressed through euphemistic usages given that death remains a taboo subject to the community under study. In this ceremony therefore, elderly members of the deceased family and some guests made speeches of caution against death and related ills. In this connection, various speakers use euphemisms through proverbs in their speeches to avoid face threatening acts thus: Firstly, speaker 'A' who was the first speaker to deliver his speech is the paternal uncle of the deceased called Ndashi and a respected head of a prominent neighborhood in Baba I called Meya. It is said that the deceased was living with him until when he left for Douala in search of greener pastures. In this light, during his burial ceremony, the said paternal uncle made a speech which he used the proverbial expression thus: "Is the person who is poor and lives not better than the person who becomes rich and dies?" This proverb which is in a form of a rhetorical question, ponders on affluence and the brevity of life. There is also the use of metaphor where he compares affluence and brevity of life to poverty and long life. It is effective in the sense that the speaker is insinuating that there is more happiness and long life in poverty than in riches. This proverb indirectly addresses ill-gotten wealth which this speaker believes could be partly responsible for the death in question. This could stem from the fact that the deceased carried out a lot of investments in the village after being in Douala just for a year which to the speaker is not normal. The underlining message in this proverb is that long life in poverty is preferable to a shorter life in affluence.

This message reflects the biblical question that "what will benefit a man if he gains the whole world and loses his soul?"This proverb therefore warns all those who indulge in illicit wealth acquisition as the consequences are disastrous. 
With respect to speaker 'B', he is the grandfather of the deceased called Bah Sali and a man reputed for moral rectitude. Being an elderly person he is perceived as a custodian of wisdom and tradition. In an aside before his speech, he affirmed that, his son (the father of the deceased) died without being on talking terms with him whom he was accused of initiating disorder in his household. In the burial ceremony of his grandson, he used in his speech the proverbial expression thus:" Does a rat go up and its child remains down? «Like theproverb spoken by speaker A, this proverb highlights the relationship between age and righteousness. The image of the rat symbolizes the deceased father or the elderly while the child represents the deceased or the older generation. In this proverb, the speaker is satirizing his son for not listening to advice resulting to the death in question.

This proverb addresses deviant attitudes inherited from the elderly. The underlining message here is that old age is not always synonymous to wisdom, so the younger generation should be very careful. The message in this proverb is related to that of the Igbo proverb that "A fly that does not listen to advice follows a corpse into the grave". It therefore calls on parents to be role models for their children. It is an appeal on the older generation to leave behind their attitude as a legacy for posterity. This view is supported by Babasola (2014) who affirms that the Yoruba accord great respect to their elders because they are the custodians of their socio-cultural heritage. Their role is summarized in the Yoruba proverb that says "when there are no elders in town, the town degenerates, when the head of the family dies, the house becomes desolate". Another says "An elder cannot be in the market and a child's head will be allowed to droop".

As regards speaker ' $\mathrm{C}$ ', he is known to be the oldest person in Papiackum called Ngaha. He is based in the village and is usually consulted to give advice in most ceremonies. Like speaker ' $\mathrm{B}$ ', he is also seen as a symbol of wisdom and tradition. In the said ceremony, he took the floor and started by lamenting on the fact that the decease alongside his entire family have always snubbed him and referred to him as a nonsense person. In the course of his speech therefore, he used the proverbial expression thus: "A bag of advice is never full. This proverb is in a form of a declarative sentence where the speaker is satirizing the deceased and his family for not seeking advice from the appropriate quarters. The speaker indirectly addresses those who are claiming to be self-sufficient with knowledge and wisdom because of their advancing age thus precipitating their death and that of their offspring. This is in line with the English proverb which says that "He, who claims to know everything, knows nothing." In this light, the speaker believes that the death in question is because the decease and his family do not have a listening ear. The idea put forth by this proverb is that the acquisition of wisdom is an ongoing process and has no age limit. This message is also reflected in the proverb which says "the doors of wisdom are never shut". This proverb also deals with the issue of humility in knowledge acquisition.

In relation to speaker ' $\mathrm{D}$ ', he was a representative of the traditional ruler of the Papiackumin the said ceremony. As usual, when such deaths occurred, the traditional ruler and his notables put in place an ad hoc commission to investigate on the cause. When the said commission finishes its work, a report is sent to the palace. The traditional ruler and his notables then meet in a closed door session, make a general observation about the death in question and give a joint report which is narrated on the said day. In the said collective report, the notable mentions the proverb thus:" White ants do not cross over water without a bridge."This proverb is wrapped in symbolic representations. White ants symbolize enemies or outsider, to cross over water represents the penetration of Papiackumand a bridge denotes an accomplice. In this light, this proverb addresses death related ills that have gained grounds among the Papiackum because they have acted as accomplices to outsiders or non-natives thus a cause of the death in question. The idea projected is that evil can never be implanted in any society without the knowledge of an insider. This proverb therefore calls for vigilance.

As for speaker 'E', she is a female neighbor of the deceased called Njengang. We learnt that she has survived food poisoning on two occasions after her only son picked up a prestigious job in a renowned parastatal. It was also alleged that she has been praying incessantly to have more children. In the said ceremony, she commenced her speech by appreciating the deceased for his kindness and good neighborliness. In the course of her speech therefore, she used the proverbial expression thus: "Who sees and likes it?'This proverb ponders on the bias nature of the said community in appreciating success. The speaker is insinuating that not everyone who appreciates a person's success does it objectively. In this guise, the speaker here indirectly addresses jealousy which she is a victim and also believes that it is partly responsible for the death in question. It is also worth mentioning that the proverbial expression above serves as a proverbial name among the Papiackum. This proverb can be likened to the English proverb which says "A wolf in sheep's clothing." In this light, it also highlights the hypocritical and evil nature of humanity. The message here is that the speaker is warning people to be careful because jealousy without justification is inherent in human beings.

In most villages in recent times, there is the urge by the natives to participate in the realization of developmental initiatives. This is the case with the community under study whose developmental objectives are realized under an association termed Baba I Development and Cultural Association (BADECA). 
The data below was collected in a fundraising meeting of the said association where various speakers highlight the need for development and its obstacles. In so doing, they avoid face threatening acts by using euphemisms in proverbs. To kick start the ceremony, the first speaker called Isofa who is termed speaker ' $\mathrm{D}$ ' is the president of the Baba I Development and Cultural Association. He has always been at the forefront of developmental initiative in the said community and has registered enormous successes. In his opening speech, he reiterates on the fact that the natives are enjoying the proceeds of initiatives but are feet dragging when called up to perform major tasks. As he proceeded with his speech, he used the proverbial expression thus:" One cannot plant pumpkins and find them bearing calabashes" This proverb projects hard work as a cornerstone to success. The speaker here hammers on natives who do not participate in developmental initiatives but wish to enjoy the fruits.

In this light, he indirectly addresses and warns against laziness. The message here is that one cannot reap where he did not sow and that success depends on hard work. This message could be likened to the idea in the proverb which says "As you make your bed, so shall you lie on it."This means that future success depends much on present choices. This proverb also warns those who do not indulge in hard work in their youthfulness for future successes only to express regret at old age.

Furthermore, speaker ' $A$ ' presented a number of developmental projects which have been realized such as the renovation of the Baba I palace, the construction of the Baba I market, the electrification of the commercial center and the installation of pipe borne water in major junctions. As he proceeded with his speech, he uses the proverb thus: "Is farm not the returning?" This proverb highlights the inseparable link between a farm and its proceeds. The farm here symbolizes developmental initiatives while the returning represents the proceeds or the successes as those cited above. The speaker addresses skeptics of developmental initiatives but who are now enjoying the successes which are feasible. The idea in this proverb is also reflected in the proverb thus "Don't cross the bridges before you come to them." This means that the natives should only criticize an initiative only when its successes are not feasible. The idea here is that successes should be measured in concrete terms and hasty criticism should be checked and discouraged. As for speaker 'B', he is the vice president of the Baba I Development and Cultural Association. He is called Ngangjoh Mama. His contribution to the Socio-economic development of Baba I cannot be over emphasized. As usual, after the president's speech, he took over the floor where he affirmed that some people complain about the mismanagement of funds for projects that have not yet been realized. As he proceeded he used the proverb thus:" One does not discuss the price of a fowl when it is in the basket" In this proverb, the price of a fowl represents the total cost of a project while being in the basket represents project that have not been completed or are still at their initial stage. The speaker in this proverb also indirectly addresses critics who believe that any developmental initiative is synonymous to mismanagement. The message here is that natives should not criticize what they have not seen or observed. This proverb is similar to the English proverbs such as "don't sell the bear's skin before you've caught it". "Don't trouble until trouble troubles you". "Draw not your bow till your arrow is fixed". This means that hasty conclusions should not be drawn from facts that have not been verified.

Moreover, Speaker ' $\mathrm{C}$ ' who is called $\mathrm{Ba}$ Tuo, is the treasurer of the said association and has been in charge of collecting funds for earmarked projects. At this juncture, he took the floor and congratulated all the natives who have been contributing financially for the realization of projects. He then proceeded by lamenting the fact that many are those who have not been contributing as they claim that because of their old age, they will not benefit much from such projects. He therefore used the proverbial expression thus:"Wise men slept in the Market". In this proverb, wise men represent those who claim to be too intelligent. He uses paradox to highlight the fact that unnecessary intelligence in certain contexts can lead to foolishness. To exemplify this, he uses the image of a market which is a place for buying and selling but which has been transformed into a bed room by the so called intelligent people. In this speech, wise men represent all those who have not been contributing financially for the realization of projects while sleeping in the market captures their folly and regrets. In effect this proverb addresses the view that too much intelligence is uncalled for. The massage here is that the speaker warns all those who claim to know everything because they know nothing. This idea is also reflected in the proverb which says the door of wisdom is never shut.

As speaker ' $C$ ' continued his speech, he affirmed that many people do not respect deadlines in giving their contributions and others have simply made promises without respecting them. He further notes that it is because of this delay that some projects take a longer time to be realized while others have not yet seen the light of day because of lack of earmarked funds. It is at this juncture, that he used the proverbial expression thus: "Someone cannot go early to the farm and later on lack what he will harvest ".

This proverb in wrapped in symbols where the farm represents developmental projects, harvest connotes the proceeds and to go early to the farm is a metaphor for embarking on developmental initiatives when it is due. The speaker here addresses procrastination which he believes has delayed the execution of projects. The message here is that the speakers is informing the natives who have been feet dragging that time waits for nobody. 
The message in this proverb can be linked to the saying thus "procrastination is the thief of time". This insinuates caution as regards time management. Finally, speaker ' $D$ ' is a native of Papiackumcalled Topewo who during the meeting was given the floor to express her views. She began by noting that she has realized that some natives contribute financially only to go behind and spread negative ideas about the said projects and those in charge of their execution. In the course of her speech, she used the proverb thus: 'To eat well, go to bed and not to be able to sleep, it is better to go to bed on empty stomach and be able to sleep well'. This proverb could be interpreted to mean that to collect financial contributions for projects and have a dirty image, it is better not to collect it and have peace of mind. The speaker here addresses back biting. In this light, she expresses the view that natives willingly contribute for the realization of projects only to turn around and mount unconstructive criticisms.

The message here is that one's image is of outmost importance. This proverb can be linked to the saying which says "A good name is better than riches". This projects the view that one's dignity in society is superior to wealth.

\section{Conclusion}

This paper has examined the two phases of proverbial expressions from the standpoint of Speech Act theoretical paradigm. The study is grounded on the role of proverbs in social interaction and their reflection on moral principles, philosophy of life and the cultural setting of the Papiackum community. This study revealed that there is the preponderant use of proverbs in the speeches of elderly people and serve as symbolic representations interpreted based on the contexts of the interactions-a burial ceremony and a fund raising ceremony. This study has also revealed the moral and philosophical undertones of these proverbs when taboos are expressed. These moral aspects range from the quest for honesty, humility and hard work while the philosophical aspects portrayed include good time management, the desire to always crave for wisdom, the belief in hard earned riches and constructive criticism. To achieve these goals, proverbs examined have used implicit speech acts like warning, requesting, informing and criticizing.

\section{References}

Abrams, M.H. (1999).A Glossary of Literary Terms. ( $7^{\text {th }}$ ed).Australia, Heinle \& Heinle.

Achebe,C.(1958).Things Fall Apart.London,Heinemann.

Ademowo, J. A., \&Balogun, O. N. (2014).Proverbs, Values and the Development Question in Contemporary Africa: A Case Study of Yoruba Proverbs.Antropologija, 14(6), 149-161.

Allan, K. \&Burridge, K. (2006).Forbidden Words: Taboos and the Censoring ofLanguage. Cambridge, Cambridge University Press.

Amende, C. (2013).Proverbs as Circumstantial Speech Acts. Research on Humanities and Social Sciences, 3(7), 10-16.

Arinola, C.A. (2009).Figures of Association and Sound in some Nigerian Proverbs: Examples from Ondo Culture. An International Multi - Disciplinary Journal, 3(3), 118-132.

Austin, L.J. (1962).How to do things with words. London, OUP: Amen House.

Babasola,J.O.(2014).The Nature, Form and Functions of Yoruba Proverbs: A Socio - Pragmatic Perspective. Journal of Humanities and Social Science, 19 (2), 44-56.

Bassis, S.M., Gelles, J.R., \&Levine, A. \& (1988).Sociology: An Introduction. ( $3^{\text {rd }}$ ed).New York, Random House.

Blumer, H. (1986).Symbolic Interactionism: Perspectives and Methods. California, UCF: Berkeley and Los Angeles.

Cook. (1967)The Voyage of the Resolution and Discovery 1776-1780.The Journals of Captain James Cook, 3,176.

Foucault. (1977).The Archaeology of Knowledge, London, Tavistock.

Lee, K. F. J. (2015). Chinese Proverbs: How are Women and Men Represented? Multi-disciplinary Journal of Gender Studies, 4(1), 559-585.

Searle, J.R. (1979).Expression and Meaning. Cambridge, UK, Cambridge University Press.

Tala, I.K. (2013).Cameroon Oral Literature: An Introduction. Kansas City, Miraclaire Academic Publishing.

Vansina, J. (1985).Oral Tradition as History. London, University of Wisconsin Press. 